\title{
KARAKTERISTIK PENDERITA SKIZOFRENIA PADA PASIEN RAWAT JALAN DI POLIKLINIK JIWA RSUD H. ANDI SULTHAN DG. RADJA KABUPATEN BULUKUMBA
}

${ }^{1}$ Hj. Fatmawati

${ }^{2}$ Nurlina

\begin{abstract}
${ }^{1}$ Departemen Keperawatan Jiwa Stikes Panrita Husada Bulukumba
${ }^{2}$ Departemen Keperawatan Jiwa Stikes Panrita Husada Bulukumba
\end{abstract}

\begin{abstract}
Alamat Korespondensi:
Ns. Hj.Fatmawati,S.Kep,M.Kep

Program Studi Ilmu Keperawatan

Sekolah Tinggi Ilmu Kesehatan Panrita Husada

Bulukumba, 04132514721

HP: 08124192999

Email:nengfatma@yahoo.co.id
\end{abstract}




\begin{abstract}
Abstrak
Skizofrenia adalah gangguan mental berat yang mempengaruhi lebih dari 21 juta orang di seluruh dunia. Menurut (Depkes RI, 2013) prevalensi gangguan jiwa berat, seperti skizofrenia adalah 1,7 per 1000 penduduk atau sekitar 400.000 orang. Skizofrenia disebabkan karena faktor multifaktorial yang terkait satu sama lain. Tujuan dari penelitian ini adalah diketahuinya Faktor-faktor yang berhubungan dengan kejadian gangguan jiwa di RSUD H.A. Sulthan Dg Radja Bulukumba tahun 2018. Penelitian ini menggunakan design Cross sectional dengan populasi sebanyak 554 orang dan sampel sebanyak 84 orang. Sampel yang digunakan dalam penelitian ini adalah non Probability Sampling dengan tehnik Sampling Purposive. Berdasarkan analisis statistik dengan menggunakan data distribusi frekuensi Hasil penelitian ini adalah berdasarkan usia penderita Skizofrenia lebih banyak pada usia dewasa, Jenis kelamin penderita Skizofrenia didapatkan laki - laki sebanyak 40 orang $(50 \%)$, dan perempuan sebanyak 40 orang responden ( $50 \%$ ), Pekerjaan penderita Skizofrenia lebih banyak yang tidak bekerja $(82,5 \%)$ dan yang bekerja sebanyak 17,5\%, Tingkat pendidikan penderita Skizofrenia lebih banyak pada pendidikan SMA ( 33,8 \%) dan pendidikan SMP dan PT sama sama sebesar 13, $8 \%$, Status perkawinan penderita Skizofrenia penderita gangguan jiwa lebih banyak dengan status kawin $(61 \%)$, Kejadian konflik keluarga penderita Skizofrenia lebih banyak yang tidak memiliki koflik dalam keluarga (85\%). Kejadian perpisahan orang tua penderita Skizofrenia lebih banyak yang tidak ada perpisahan orang tua $(85 \%)$, Status sosial ekonomi penderita Skizofrenia dalam status ekonomi kurang 66 orang ( 82,5\%, Pola asuh orangtua penderita Skizofrenia pola asuh demokratis 75 orang atau 93,8\%. Diharapkan agar kiranya hasil penelitian ini dapat dipakai sebagai bahan bacaan ilmiah diperpustakaan dan juga dapat dipakai sebagai bahan referensi yang meneliti masalah yang sejenisnya.
\end{abstract}

Kata Kunci: Skizofrenia, Gangguan jiwa

\begin{abstract}
Schizophrenia is a severe mental disorder that affects more than 21 million people worldwide. According to (Ministry of Health, 2013) the prevalence of severe mental disorders, such as schizophrenia, is 1.7 per 1000 residents or around 400,000 people. Schizophrenia is caused by multifactorial factors that are related to each other. The purpose of this study was to find out the factors associated with the incidence of mental disorders in H.AUD Hospital. Sulthan with Radja Bulukumba in 2018. This study uses Cross sectional design with a population of 554 people and a sample of 84 people. The sample used in this study is non probability sampling with purposive sampling technique. Based on statistical analysis using frequency distribution data The results of this study are based on the age of Schizophrenia sufferers more in adulthood, the sex of Schizophrenic patients is obtained by men as many as 40 people (50\%), and women as many as 40 respondents (50\%), Job Schizophrenia sufferers are more unemployed $(82.5 \%)$ and those who work are $17.5 \%$, the education level of Schizophrenics is higher in high school education (33.8\%) and junior and PT education is equal to 13, 8\%, The marital status of schizophrenics sufferers with mental disorders is more with marital status (61\%), there are more conflicts in families with schizophrenia who do not have a family conflict (85\%). Farewell events of Schizophrenia sufferers more than no parents (85\%), Socio-economic status of schizophrenics in economic status less than 66 people (82.5\%, Parenting schizophrenic parents democratic parenting 75 people or $93.8 \%$. It is expected that the results of this study may be used as scientific reading material in the library and can also be used as reference material that examines similar problems.
\end{abstract}

Keywords: Schizophrenia, mental disorders 
PENDAHULUAN

Kesehatan jiwa yang dialami penduduk di dunia terus mengalami peningkatan yaitu dari penduduk yang menderita kelainan jiwa dari rasa stress, cemas, depresi, pengunaan obat, kenakalan remaja, sampai skizofrenia. Dari banyaknya gangguan jiwa ada salah satu gangguan jiwa terberat yaitu skizofrenia (Arianti, Novera, \& Rosa, 2017).

Skizofrenia yaitu seseorang yang memiliki masalah kejiwaan, atau kepribadian yang terganggu seperti pikiran, perasaan, pendengaran, emosi, bahasa, delusi, serta perilaku yang tidak sesuai sebagaimana manusia normal lainnya(Prabowo, 2014). Faktor-faktor yang mempengaruhi kambuhnya penyakit skizofrenia yang diteliti yaitu dari faktor dukungan keluarga, usia, faktor kepatuhan minum obat,,jenis kelamin, pendidikan, fakto rekonomi. Alasan Apabila penyakit ini tidak di tangani maka akan menimbulkan dampak yang akan merugikan dan membahayakan pasien, keluarga, dan masyarakat karena dapat berperilaku menyimpang misalnya: mengamuk, bertindak sesukanya, menghancukan barang-barang atau pasien akan melukai orang lain bahkan diri sendiri (Kurnia, Tyaswati, \& Abrori, 2015).
Pada tahun 1996, Global Burden of Disease Study memeriksa 107 penyakit di seluruh dunia, terdapat lima masalah kesehatan mental yang menjadi penyebab utama kecacatan fisik di negara maju yaitu, depresi berat, penyalah gunaan alkohol, skizofrenia, luka ditimbulkan sendiri, gangguan bipolar (Murray dan Lopez, 1996) dan diperkirakan Pada tahun 2020 gangguan mental dan penyalahgunaan obat terlarang akan melampaui semua penyakit fisik sebagai penyebab utama kecacatan di seluruh dunia.

Menurut World Health Organization (WHO) menyebutkan bahwa Skizofrenia adalah gangguan mental berat yang mempengaruhi lebih dari 21 juta orang di seluruh dunia diperkirakan $4,4 \%$ dari populasi global menderita gangguan depresi, dan 3,6\% mengalami gangguan kecemasan. Jumlah penderita depresi meningkat lebih dari $18 \%$ antara tahun 2005 dan 2015 (WHO, 2017).Sedangkan menurut (Depkes RI, 2013) prevalensi gangguan jiwa berat, seperti skizofrenia adalah 1,7 per 1000 penduduk atau sekitar 400.000 orang.

Berdasarkan data Riskesdas tahun 2013 jumlah penderita gangguan jiwa berat (ODGJ) sebesar 0, $17 \%$ dari Total penduduk dan jumlah penderita Gangguan 
jiwa tertinggi yaitu Aceh dan Jogyakarta sebesar 0, 27 \%, Kedua Sulawesi Selatan 0, $26 \%$, dan ketiga yaitu Jawa Tengah dan Bali 0, $23 \%$. Diperkirakan Jumlah penduduk Indonesia 250 juta , ODGJ Ringan sebanyak 15 juta orang, ODGJ 425 ribu orang, dan yang dipasung sebanyak 60 ribu orang.

Menurut data yang diperoleh dari Bagian Poliklinik Jiwa RSUD $H$. A. Sulthan Dg Radja Kab. Bulukumba pada jumlah kunjungan penderita rawat jalan di poliklinik Jiwa pada Bulan Maret sebanyak 354 orang, April 331 orang, Mei 348 orang, Juni 410 orang dengan persentase kejadian skizofrenia sebanyak $80 \%$.

Skizofrenia berdampak pada finansial, yang berpengaruh pada individu yang mengalami, keluarga dan masyarakat, karena masih terdapatnya pandangan negatif (stigma), pasien serta keluarganya sering mendapat penolakan sosial dari masyarakat akibat ketidaktahuan masyarakat terhadap jenis gangguan jiwa.

Skizofrenia disebabkan karena factor multifaktorial yang terkait satu sama lain. Menurut model diatesis stress, integrasi antara faktor biologis, faktor psikososial dan faktor lingkungan dapat menimbulkan skizofrenia. Seseorang yang rentan (diatesis) jika dikenai stresor akan lebih mudah untuk menjadi skizofrenia.

Menurut Maramis, sumber penyebab gangguan jiwa dipengaruhi oleh faktor somatik, faktor psikologik dan faktor sosio-budaya yang secara terusmenerus saling mempengaruhi. Munculnya gejala skizofrenia diakibatkan dari adanya perubahan pola lingkungan, perilaku dan akibat kondisi biologik individu tersebut. Pada perkembangan psikologi yang salah terjadi ketidakmatangan atau fiksasi bahwa individu gagal berkembang lebih lanjut pada fase berikutnya dan ada tempattempat yang lemah (rentan). Individu yang rentan tersebut apabila dikenai stress psikososial seperti status ekonomi yang rendah, gagal dalam mencapai cita-cita dan konflik yang berlarut-larut, kematian keluarga yang dicintai dan lain sebagainya dapat berkembang menjadi gangguan jiwa skizofrenia. Ada beberapa faktor psikososial yang mempengaruhi gangguan jiwa skizofrenia, yaitu sosial ekonomi rendah dan stres lingkungan.

Menurut Mallett et al bahwa kehilangan orangtua dan pengangguran merupakan faktor psikososial yang dapat mempengaruhi terjadinya gangguan jiwa skizofrenia. Konflik keluarga sangat mempengaruhi perkembangan 
psikopatologis anak. Konflik dalam keluarga juga akan mempengaruhi sikap atau didikan orangtua terhadap anak, dan sikap orangtua sangat berpengaruh terhadap pola asuh kepada anak. Pola pengasuhan orangtua mempengaruhi perkembangan perilaku sosial anak. Terjadinya psikosis atau skizofrenia kemungkinan disebabkan pada masa kanak-kanaknya mendapatkan perlakuan kekerasan, sehingga menimbulkan trauma yang mendalam pada diri anak.

\section{METODE}

Desain penelitian ini merupakan penelitian menggunakan desain Analitik dengan menggunakan pendekatan cross sectional adalah rancangan penelitian dengan melakukan pengukuran atau pengamatan pada saat bersama hanya sekali dalam satu saat, akan tetapi tidak semua subjek penelitian diteliti pada waktu yang sama. (Hidayat A. A., 2014).

Populasi dalam penelitian ini adalah pasien skizofrenia yang berkunjung ke Poliklinik jiwa RSUD $\mathrm{H}$. Andi Sulthan Dg. Radja Bulukumba sebanyak 332 responden. Metode penarikan sampel menggunakan non probability sampling dengan metode fixed disease sampling Dalam penelitian ini jumlah sampel sebanyak 80 responden.
Instrumen yang digunakan dalam penelitian ini adalah dengan memberikan melakukan wawancara menggunakan format wawancara terstruktur Kuesioner dalam penelitian ini berupa bentuk pernyataan untuk setiap faktor menggunakan skala guttman dengan kategori jawaban ya di beri skor 1 dan tidak di beri skor 0 .

Data dianalisis berdasarkan skala ukur dan tujuan penelitian dengan menggunakan perangkat lunak program komputerisasi. Data dianalisis secara univariat, Analisis dilakukan untuk melihat proporsi.

\section{HASIL}

Berdasarkan tabel 1 dari 80 responden dewasa lebih banyak yaitu sebanyak 47 orang $(58,8 \%)$, dan lansia sebanyak 33 orang responden $(41,3 \%)$. Berdasarkan tabel 2 dari 80 responden didapatkan laki - laki sebanyak 40 orang (50\%), dan perempuan sebanyak 40 orang responden ( $50 \%$ ). Berdasarkan tabel 3 pekerjaan responden penderita gangguan jiwa lebih banyak yang tidak bekerja $(82,5 \%)$ dan yang bekerja sebanyak $17,5 \%$. Berdasarkan tingkat pendidikan responden penderita gangguan jiwa lebih banyak pada pendidikan SMA ( $33,8 \%$ ) dan pendidikan SMP dan PT sama sama 
sebesar 13, $8 \%$. Berdasarkan status perkawinan responden penderita gangguan jiwa lebih banyak dengan status kawin $(61 \%)$. Berdasarkan kejadian konflik dalam keluarga responden penderita skozofrenia lebih banyak yang tidak memiliki koflik dalam keluarga $(85 \%)$. Berdasarkan kejadian perpisahan orang tua dalam keluarga responden penderita skozofrenia lebih banyak yang tidak ada perpisahan orang tua $(85 \%)$. Berdasarkan status ekonomi penderita skizofrenia dalam dalam status ekonomi kurang 66 orang ( $82,5 \%)$. Berdasarkan tabel 10 pola asuh keluarga penderita skizofrenia yaitu pola asuh demokratis 75 orang atau $93,8 \%$.

\section{PEMBAHASAN}

Penelitian ini terlihat bahwa karakteristik penderita Skizofrenia pada pasien rawat jalan di poliklinik Jiwa RSUD H. Andi Sulthan Dg. Radja Kab. Bulukumba tahun 2018 berdasarkan usia lebih banyak pada usia dari 80 responden dewasa lebih banyak yaitu sebanyak 47 orang $(58,8 \%)$, dan lansia sebanyak 33 orang responden $(41,3 \%)$.

Karakteristik usia sebagian besar responden berada pada kategori dewasa yaitu 58,8 \%. Hal ini sejalan dengan penelitian yang dilakukan oleh Heslin dan

Weiss (2015), yang menemukan bahwa penderita skizofrenia lebih banyak pada usia kanak - kanak remaja dan lansia. Menurut Hoffman, 1994 bahwa usia memiliki prediksi yang tinggi dalam kejadian rehospitalisasi dan memiliki hubungan yang signifikan.

Berdasarkan jenis kelamin dari 80 responden didapatkan laki - laki sebanyak 40 orang $(50 \%)$, dan perempuan sebanyak 40 orang responden ( $50 \%$ ). Hal ini tidak sesuai dengaan penelitian yang dilakukan oleh Yegenoglu, 2003 yang menemukan bahwa laki laki lebih banyak yang menderita gangguan jiwa dibandingkan dengan perempuan.

Karakakteristik responden berikutnya adalah pekerjaan didapatkan bahwa sebagian besar responden tidak memiliki pekerjaan yaitu sebesar $82,5 \%$. Hal ini sejalan dengan hasil penelitian yang dilakukan oleh Saputri yang mengatakan bahwa mobilitas yang tinggi berdampak pada timbulnya gangguan ketenagaan yang disebabkan adanya tekanan dalam pekerjaan dan ekonomi, permasalahan sosial dan lain sebanyaknya menjadi faktor stressor untuk timbulnya gangguan jiwa pada seseorang.

Karakteristik

berdasarkan pendidikan responden penderita gangguan jiwa lebih banyak 
pada pendidikan SMA ( $33,8 \%$ ) dan pendidikan SMP dan PT sama sama sebesar 13, $8 \%$. Berdasarkan hal ini maka dapat disimpulkan bahwa tingkat pendidikan tidak ada hubungan dengan kejadian skizofrenia.

Status perkawinan penderita skizofrenia yang responden penderita gangguan jiwa lebih banyak dengan status kawin $(61 \%)$. Hal ini sejalan dengan penelitian sebelumnya yang dilakukan oleh Handayani Dkk (2015) yang menemukan bahwa faktor psikososial memiliki nilai $\mathrm{P}=0.002$ yang artinya ada hubungan bermakna antara stressor psikososial dengan terjadinya gangguan jiwa.

Berdasarkan kejadian konflik dalam keluarga responden penderita skozofrenia lebih banyak yang tidak memiliki koflik dalam keluarga (85\%). Hal ini tidak sesuai dengan pendapat bahwa Konflik dalam keluarga juga akan mempengaruhi sikap atau didikan orangtua terhadap anak, dan sikap orangtua sangat berpengaruh terhadap pola asuh kepada anak. Pola pengasuhan orangtua mempengaruhi perkembangan perilaku sosial anak. Terjadinya psikosis atau skizofrenia kemungkinan disebabkan pada masa kanak-kanaknya mendapatkan perlakuan kekerasan, sehingga menimbulkan trauma yang mendalam pada diri anak.

Berdasarkan status ekonomi penderita skizofrenia dalam status ekonomi kurang 66 orang ( 82,5\%). Hal ini sejalan dengan hasil penelitian yang dilakukan oleh Saputri yang mengatakan bahwa mobilitas yang tinggi berdampak pada timbulnya gangguan ketenagaan yang disebabkan adanya tekanan dalam pekerjaan dan ekonomi, permasalahan sosial dan lain sebanyaknya menjadi faktor stressor untuk timbulnya gangguan jiwa pada seseorang.

Karakteristik pola asuh keluarga penderita skizofrenia yaitu pola asuh demokratis 75 orang atau 93,8\%. Hal ini tidak sesuai dengan teori yang mngemukakan bahwa pola asuh demokratis ini merupakan pola asuh yang paling baik. Dimana orang tua bersikap bersahabat dan anak bebas mengemukakan pendapatnya. Disini orang tua lebih mau mendengar keluhan dari anaknya, mau memberikan masukan. Ketika anaknya diberi hukuman, orang tua menjelaskan kenapa dia harus dihukum. Pola asuh ini menurut tidak banyak dimiliki oleh orang tua zaman sekarang. Contoh dari pola asuh ini, dimana orang tua mau mendengarkan curhat dari 
anaknya, mau memberikan solusi dari masalah yang dihadapi anaknya.

\section{KESIMPULAN DAN SARAN}

Usia penderita Skizofrenia lebih banyak pada usia dewasa, Jenis kelamin penderita Skizofrenia didapatkan laki laki dan perempuan sama banyak, Pekerjaan penderita Skizofrenia lebih banyak yang tidak bekerja, Tingkat pendidikan penderita Skizofrenia lebih banyak pada pendidikan SMA, Status perkawinan penderita Skizofrenia penderita gangguan jiwa lebih banyak dengan status kawin, kejadian konflik keluarga penderita Skizofrenia lebih banyak yang tidak memiliki koflik dalam keluarga, Kejadian perpisahan orang tua penderita Skizofrenia lebih banyak yang tidak ada perpisahan orang tua, Status sosial ekonomi penderita Skizofrenia lebih banyak yang status ekonomi kurang serta pola asuh orangtua penderita Skizofrenia mayoritas pola asuh demokratis. Disarankan kepada penelitian selanjutnya untuk melakukan intervensi pencegahan kejadian skiszofrenia pada tingkat indivisu, keluarga dan masyarakat untuk melakukan pencegahan kejadian dan bagi klien yang telah mengalami kejadian skizofrenia untuk dilakukan intervensi penanganan gangguan.

\section{DAFTAR PUSTAKA}

Diana Arianti, Milya Novera, Afrida Yani Rosa . Hubungan Pola Asuh Keluarga dengan kekambuhan pasien skozfrenia di RSJ HB. Saanin Padang, tahun 2017. Skripsi S1 Keperawatan STIKES Alifah Padang.

Dirjen Bina Kesehatan Masyarakat. 2014. Profil Kesehatan Masyarakat Tahun 2013. Jakarta : Dirjen Bina Kesehatan Masyarakat.

Kaplan, H.I., Sadock, B.J., and Grebb, J.A., 2010. Sinopsis Psikiatri : Ilmu Pengetahuan Perilaku Psikiatri Klinis. Jilid Dua. Editor : Dr. I. Made

Wiguna S. Jakarta : Bina Rupa Aksara Keliat, BA. 2007. Peran Serta Keluarga Dalam Perawatan Klien Gangguan Jiwa. EGC. Jakarta

Maramis, F.W. 2009. Ilmu Kedokteran Jiwa. Airlangga University Press : Surabaya 
Notoadmodjo, S. 2012. Metodologi Sugiyono. 2011. Metode Penelitian

Penelitian Kesehatan. Rineka Cipta : Kuantitatif, Kualitatif, dan R \& D. Jakarta Bandung : Alfabeta

Riset Kesehatan Dasar (Rikesdas). 2013.

Badan Penelitian dan Pengembangan

Kesehatan Republik Indonesia. Jakarta.

Sadock BJ, Sadock VA. Kaplan \& Sadock's. 2015. Synopsis of Psychiatry. Behavior Sciences/Clinical Psychiatry. 10th 2. ed. Lippincott Williams \& Wilkins, p.527-30.

Stuart GW, Sundeen SJ. 2007. Buku Saku Keperawatan Jiwa. Edisi 5 : Jakarta : EGCSugiyono, 2008 
Tabel 1

Distribusi umur penderita Skizofrenia di Poliklinik Jiwa RSUD H. Andi Sulthan Dg. Radja di Kabupaten Bulukumba

Tahun 2018

\begin{tabular}{ccc}
\hline Umur & Frequency & Percent \\
\hline Dewasa & 47 & 58,8 \\
Lansia & 33 & 41,3 \\
\hline Jumlah & $\mathbf{8 0}$ & $\mathbf{1 0 0}$ \\
\hline
\end{tabular}

Tabel 2

Distribusi Jenis kelamin responden gangguan jiwa di Poliklinik Jiwa RSUD H. Andi Sulthan Dg. Radja di Kabupatn Bulukumba

Tahun 2018

\begin{tabular}{|c|c|c|}
\hline Jenis Kelamin & $\mathrm{F}$ & $\%$ \\
\hline Laki - laki & 40 & 50 \\
\hline Perempuan & 40 & 50 \\
\hline Jumlah & 80 & 100.0 \\
\hline
\end{tabular}

Tabel 3

Distribusi Pekerjaan responden gangguan jiwa di Poliklinik Jiwa RSUD H. Andi Sulthan Dg. Radja di Kabupaten Bulukumba

Tahun 2018

\begin{tabular}{ccc}
\hline Pekerjaan & F & $\%$ \\
Bekerja & 14 & 17,5 \\
Tidak Bekerja & 66 & 82,5 \\
\hline Jumlah & $\mathbf{8 0}$ & $\mathbf{1 0 0}$ \\
\hline
\end{tabular}


Tabel 4

Distribusi Tingkat pendidikan responden gangguan jiwa di Poliklinik Jiwa RSUD H. Andi Sulthan Dg. Radja di Kabupaten Bulukumba

Tahun 2018

\begin{tabular}{ccc}
\hline Pendidikan & F & $\%$ \\
Tidak Sekolah & 15 & 18,8 \\
SD & 16 & 20,0 \\
SMP & 11 & 13,8 \\
SMA & 27 & 33,8 \\
PT & 11 & 13,8 \\
\hline Jumlah & $\mathbf{8 0}$ & $\mathbf{1 0 0 , 0}$ \\
\hline
\end{tabular}

Tabel 5

Distribusi Status Perkawinan responden penderita gangguan jiwa di Poliklinik Jiwa RSUD H. Andi Sulthan Dg. Radja di Kabupaten Bulukumba Tahun 2018

\begin{tabular}{ccc}
\hline Status perkawinan & F & $\%$ \\
Kawin & 61 & 76,3 \\
Tidak Kawin & 13 & 16,3 \\
Cerai & 6 & 7,5 \\
\hline Jumlah & $\mathbf{8 0}$ & $\mathbf{1 0 0}$ \\
\hline
\end{tabular}

Tabel 7

Distribusi kejadian konflik keluarga responden penderita gangguan jiwa di Poliklinik Jiwa RSUD H. Andi Sulthan Dg. Radja di Kabupaten Bulukumba Tahun 2018

\begin{tabular}{ccc}
\hline Konflik Keluarga & F & $\%$ \\
Tidak ada & 68 & 85 \\
Ada & 12 & 15 \\
\hline Jumlah & $\mathbf{8 0}$ & $\mathbf{1 0 0}$ \\
\hline
\end{tabular}


Tabel 8

Distribusi kejadian perpisahan orang tua responden skizofrenia di Poliklinik Jiwa RSUD H. Andi Sulthan Dg. Radja di Kabupaten Bulukumba Tahun 2018

\begin{tabular}{ccc}
\hline Perpisahan orang tua & F & $\%$ \\
Tidak ada & 68 & 85 \\
Ada & 12 & 15 \\
\hline Jumlah & $\mathbf{8 0}$ & $\mathbf{1 0 0}$ \\
\hline
\end{tabular}

Tabel 9

Distribusi Status Ekonomi responden skizofrenia di Poliklinik Jiwa

RSUD H. Andi Sulthan Dg. Radja di Kabupaten Bulukumba Tahun 2018

\begin{tabular}{ccc}
\hline Status ekonomi & F & $\%$ \\
Kurang & 66 & 82,5 \\
Cukup & 14 & 17,5 \\
\hline Jumlah & $\mathbf{8 0}$ & $\mathbf{1 0 0}$ \\
\hline
\end{tabular}

Tabel 10

Distribusi Pola asuh orang tua responden penderita skizofrenia di Poliklinik Jiwa RSUD H. Andi Sulthan Dg. Radja di Kabupaten Bulukumba Tahun 2018

\begin{tabular}{ccc}
\hline Pola Asuh & F & $\%$ \\
Demokratis & 75 & 93,8 \\
Permisif & 3 & 3,8 \\
Otoriter & 2 & 2,5 \\
\hline Jumlah & $\mathbf{8 0}$ & $\mathbf{1 0 0}$ \\
\hline
\end{tabular}

